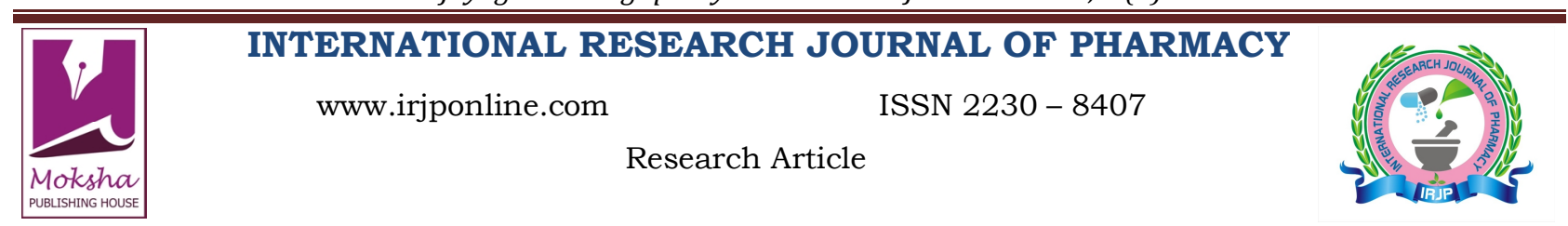

\title{
SIMULTANEOUS SPECTROPHOTOMETRIC DETERMINATION OF DIACEREIN AND ACECLOFENAC IN TABLETS BY CHEMOMETRIC METHODS
}

Vijayageetha Ragupathy*, Shantha Arcot

Department of Pharmaceutical Analysis, Faculty of Pharmacy, C.L Baid Metha College of Pharmacy, Thoraipakkam, Chennai, Tamil Nadu, India

Email: venista7@gmail.com

Article Received on: 16/01/13 Revised on: 01/02/13 Approved for publication: 03/03/13

DOI: $10.7897 / 2230-8407.04345$

IRJP is an official publication of Moksha Publishing House. Website: www.mokshaph.com

(C) All rights reserved.

\section{ABSTRACT}

Simultaneous spectrophotometric determination of diacerein and aceclofenac was performed by partial least-squares (PLS) and principal component regression (PCR) methods do not require any priori graphical treatment of the overlapping spectra of two drugs in the mixture. The absorbance values in the UV-Vis spectra were measured for the 67 wavelength points (from 234-300) in the spectral region $200-400 \mathrm{~nm}$ considering the intervals of $1 \mathrm{~nm}$. The calibration range was found to be $1-5 \mu \mathrm{g} / \mathrm{ml}$ for diacerein, $2-10 \mu \mathrm{g} / \mathrm{ml}$ for aceclofenac with a correlation coefficient of 0.9998 (PLS), 0.9995 (PCR) for diacerein and 0.9999 (PLS), 0.9997 (PCR) for aceclofenac. The validation of the multivariate methods was realized by analyzing the synthetic mixtures of diacerein and aceclofenac. The numerical calculations were performed with the 'Unscrambler $10.1 \mathrm{X}$ ' software. The chemometrics analysis methods were satisfactorily applied to the simultaneous determination of diacerein and aceclofenac in the pharmaceutical formulation.

Keywords: aceclofenac, chemometrics, diacerein, spectrophotometry, partial least square, principal component regression.

\section{INTRODUCTION}

Diacerein (DIA) is chemically 1, 8-Diacetoxy-3carboxyanthraquinone which is used as an analgesic, antipyretic and anti inflammatory Agent ${ }^{1-2}$. Aceclofenac (ACE) chemically described Aceclofenac (ACE) is 2-[2-[2(2, 6-Dichlorophenyl) amino phenyl acetyl] oxy acetic acid. Aceclofenac is used as anti-inflammatory drug ${ }^{3}$. Literature survey reveals diacerein and Aceclofenac were simultaneously estimated by UV spectrophotometric methods $^{4-10}$.HPLC $^{11-16}$ and HPTLC ${ }^{17-18}$. No chemometric method is reported for the simultaneous determination of diacerein and aceclofenac in bulk and tablet dosage forms. The present article discusses the attempts made to develop simple, sensitive, reproducible and economical chemometric methods for simultaneous determination of these drugs in dosage forms.

In recent years, multivariate calibrations, such as classical least-squares (CLS), inverse least-squares (ILS), principal component regression (PCR) and partial least-squares (PLS) are started to apply to the analysis of the analytical data obtained in all the instrumentations ${ }^{19-20}$.It is probably the area within chemometrics which has attracted the most interest so far. The approach is useful in the simultaneous spectrophotometric determination of two or more components in a pharmaceutical formulation with overlapping spectra. These are extensively used in quantitative spectral analysis to get selective information from unselective data. These methods have been found to be the method of choice for complex mixtures. The advantage of multi-component analysis using multivariate calibration is the speed of the determination of components in a mixture, avoiding a preliminary separation step. The control analysis on pharmaceutical formulations using the multivariate calibration methods has been proved to be a valid alternative to HPLC.

The objective of this paper is to investigate the ability of PLS and PCR models to quantify the binary mixture of DIA and ACE with overlapped UV spectra and to apply the optimised models in pharmaceutical formulations. The proposed methods are simple and accurate, resulted in a significant reduction in analysis time and proved to be suitable for routine determination of the two components of the standard mixture.

\section{MATERIALS \& METHODS}

\section{Instruments and software}

Digitized UV/VIS absorbency spectra were collected using a UV-visible spectrometer 2300 Techcomp with $1 \mathrm{~cm}$ quartz cells. The data acquisition was made with UV solutions software at a scan rate of $1000 \mathrm{~nm} \mathrm{~min}-1$ and the slit width of $2 \mathrm{~nm}$. The UV spectra of mixtures were recorded over the wavelength 234-300 nm with one data point per nm. All spectral measurements were performed using blank solution as a reference. Partial least squares regression, and principal component regression were used for chemometric analysis of data. For all calculations Unscrambler for windows (Version 10.1 X) was used.

\section{Pharmaceutical tablet formulations}

A commercial pharmaceutical formulation (DYCERIN-A) tablet containing $50 \mathrm{mg}$ of DIA and $100 \mathrm{mg}$ of ACE was analysed by the proposed chemometric methods.

\section{Standard solutions}

Stock solutions of Diacerein and aceclofenac of $10 \mathrm{mg}$ were prepared in $100 \mathrm{ml}$ volumetric flasks with methanol. The training set containing $1-5 \mu \mathrm{g} / \mathrm{ml}$ diacerein and $2-10 \mu \mathrm{g} / \mathrm{ml}$ aceclofenac working standard solutions were prepared by diluting the stock solutions for each drug according to its linear calibration range. Two sets of standard solutions were prepared, the calibration set contained 25 standard solutions and the prediction set contained 9 standard solutions. To a series of $10 \mathrm{ml}$ volumetric flasks, aliquots of diacerein and aceclofenac solutions, containing appropriate amount of these drugs in the range of calibrations, were added and then the solutions were diluted to $10 \mathrm{ml}$ with methanol. UV spectra of the mixtures were recorded in the wavelength range 234-300 $\mathrm{nm}$ versus a solvent blank, and digitized absorbance was 
sampled at $1 \mathrm{~nm}$ intervals. All the solutions were prepared freshly and were protected from light.

\section{Sample preparations}

Twenty tablets were accurately weighed and powdered in a mortar. An amount of the powder equivalent was weighed and dissolved in methanol in $100 \mathrm{ml}$ calibrated flasks. $20 \mathrm{ml}$ of methanol was added and ultra sonicated for 25 minutes and the volume was made up to100 $\mathrm{ml}$ with methanol and shake well. Then, the solution was filtered through what man filter paper No. 41 and the residue was washed three times with 10 $\mathrm{ml}$ of solvent, and then the volume was completed to $100 \mathrm{ml}$ with methanol. The resulting solution was diluted to $1: 2$ in a $100 \mathrm{ml}$ calibrated flasks. Both techniques were applied to the prepared sample solutions.

\section{RESULTS \& DISCUSSIONS}

The absorption spectra of DIA and ACE solutions in methanol recorded between 234 - $300 \mathrm{~nm}$ were shown in Figure 1. The two drugs show an overlap in their absorption.

Table 1: Composition of calibration (Training set) for PLS and PCR methods

\begin{tabular}{|c|c|c|c|c|c|c|}
\hline \multirow{3}{*}{ S.NO } & \multicolumn{3}{|c|}{ Diacerein } & \multicolumn{3}{|c|}{ Aceclofenac } \\
\hline & \multirow[t]{2}{*}{ Reference $\mu \mathrm{g} / \mathrm{ml}$} & \multicolumn{2}{|c|}{ Predicted $\mu \mathrm{g} / \mathrm{ml}$} & \multirow{2}{*}{$\begin{array}{c}\text { Reference } \\
\mu \mathrm{g} / \mathrm{ml}\end{array}$} & \multicolumn{2}{|c|}{ Predicted $\mu \mathrm{g} / \mathrm{ml}$} \\
\hline & & PLS & PCR & & PLS & PCR \\
\hline 1 & 1.00 & 1.09 & 1.04 & 2.00 & 2.10 & 2.05 \\
\hline 2 & 1.00 & 1.08 & 1.04 & 4.00 & 3.98 & 3.95 \\
\hline 3 & 1.00 & 1.07 & 1.04 & 6.00 & 6.03 & 6.00 \\
\hline 4 & 1.00 & 1.06 & 1.04 & 8.00 & 7.97 & 7.96 \\
\hline 5 & 1.00 & 1.05 & 1.04 & 10.00 & 10.05 & 10.04 \\
\hline 6 & 2.00 & 1.99 & 1.95 & 2.00 & 2.09 & 2.05 \\
\hline 7 & 2.00 & 1.98 & 1.95 & 4.00 & 3.97 & 3.95 \\
\hline 8 & 2.00 & 1.97 & 1.95 & 6.00 & 6.02 & 6.00 \\
\hline 9 & 2.00 & 1.96 & 1.95 & 8.00 & 7.96 & 7.96 \\
\hline 10 & 2.00 & 1.95 & 1.95 & 10.00 & 10.04 & 10.04 \\
\hline 11 & 3.00 & 3.02 & 2.99 & 2.00 & 2.08 & 2.05 \\
\hline 12 & 3.00 & 3.01 & 2.99 & 4.00 & 3.96 & 3.95 \\
\hline 13 & 3.00 & 2.99 & 2.99 & 6.00 & 6.01 & 6.00 \\
\hline 14 & 3.00 & 2.98 & 2.99 & 8.00 & 7.95 & 7.96 \\
\hline 15 & 3.00 & 2.97 & 2.99 & 10.00 & 10.03 & 10.04 \\
\hline 16 & 4.00 & 4.01 & 3.99 & 2.00 & 2.07 & 2.05 \\
\hline 17 & 4.00 & 4.00 & 3.99 & 4.00 & 3.95 & 3.95 \\
\hline 18 & 4.00 & 3.99 & 3.99 & 6.00 & 6.00 & 6.00 \\
\hline 19 & 4.00 & 3.98 & 3.99 & 8.00 & 7.94 & 7.96 \\
\hline 20 & 4.00 & 3.97 & 3.99 & 10.00 & 10.02 & 10.04 \\
\hline 21 & 5.00 & 5.03 & 5.02 & 2.00 & 2.06 & 2.05 \\
\hline 22 & 5.00 & 5.02 & 5.02 & 4.00 & 3.94 & 3.95 \\
\hline 23 & 5.00 & 5.01 & 5.02 & 6.00 & 5.99 & 6.00 \\
\hline 24 & 5.00 & 5.00 & 5.02 & 8.00 & 7.93 & 7.96 \\
\hline 25 & 5.00 & 4.99 & 5.02 & 10.00 & 10.01 & 10.04 \\
\hline
\end{tabular}

Table 2: Composition of validation (Prediction set) for PLS and PCR methods

\begin{tabular}{|c|c|c|c|c|c|c|}
\hline \multirow[t]{3}{*}{ S.NO } & \multicolumn{3}{|c|}{ Diacerein } & \multicolumn{3}{|c|}{ Aceclofenac } \\
\hline & \multirow{2}{*}{$\begin{array}{c}\text { Reference } \\
\mu \mathrm{g} / \mathrm{ml}\end{array}$} & \multicolumn{2}{|c|}{ Predicted $\mu \mathrm{g} / \mathrm{ml}$} & \multirow{2}{*}{$\begin{array}{c}\text { Reference } \\
\mu \mathrm{g} / \mathrm{ml}\end{array}$} & \multicolumn{2}{|c|}{ Predicted $\mu \mathrm{g} / \mathrm{ml}$} \\
\hline & & PLS & PCR & & PLS & PCR \\
\hline 1 & 1.5 & 1.59 & 1.55 & 3.00 & 2.98 & 2.94 \\
\hline 2 & 1.5 & 1.58 & 1.55 & 5.00 & 5.06 & 5.04 \\
\hline 3 & 1.5 & 1.57 & 1.55 & 7.00 & 7.02 & 7.00 \\
\hline 4 & 2.5 & 2.49 & 2.46 & 3.00 & 2.97 & 2.94 \\
\hline 5 & 2.5 & 2.48 & 2.46 & 5.00 & 5.06 & 5.04 \\
\hline 6 & 2.5 & 2.47 & 2.46 & 7.00 & 7.01 & 7.00 \\
\hline 7 & 3.5 & 3.48 & 3.46 & 3.00 & 2.96 & 2.94 \\
\hline 8 & 3.5 & 3.47 & 3.46 & 5.00 & 5.05 & 5.04 \\
\hline 9 & 3.5 & 3.46 & 3.46 & 7.00 & 7.00 & 7.00 \\
\hline
\end{tabular}

Table 3: Summary of statistics in PLS and PCR methods

\begin{tabular}{|c|c|c|c|c|c|c|c|c|c|c|}
\hline \multirow[t]{2}{*}{ Drug } & \multicolumn{2}{|c|}{ RMSEP } & \multicolumn{2}{|c|}{ RMSEC } & \multicolumn{2}{|c|}{$\mathbf{r}^{2}$} & \multicolumn{2}{|c|}{ Intercept } & \multicolumn{2}{|c|}{ Slope } \\
\hline & PLS & PCR & PLS & PCR & PLS & PCR & PLS & PCR & PLS & PCR \\
\hline Dia & 0.0498 & 0.0420 & 0.0377 & 0.0306 & 0.9998 & 0.9995 & 0.0397 & 0.0014 & 0.9890 & 0.9995 \\
\hline Ace & 0.0377 & 0.0398 & 0.0473 & 0.0428 & 0.9999 & 0.9997 & 0.0362 & 0.0013 & 0.9950 & 0.9997 \\
\hline
\end{tabular}

Dia-diacerein, Ace- aceclofenac, RMSEP-Root mean square error of prediction, RMSEC-Root mean square error of calibration and $\mathrm{r}^{2-}$ Correlation coefficient.

Table 4: Analysis of tablet formulation (Assay)

\begin{tabular}{|c|c|c|c|}
\hline Formulation & Label claim & PLS mg/tab found* & PCR mg/tab found* \\
\hline \multirow{2}{*}{ DYCERIN-A } & Dia 50mg & 49.98 & 49.98 \\
\cline { 2 - 4 } & Ace $100 \mathrm{mg}$ & 100.27 & 100.27 \\
\hline
\end{tabular}

*Each value is a mean of six readings 
Vijayageetha Ragupathy et al. Int. Res. J. Pharm. 2013, 4 (3)

Table 5: Precision Data

\begin{tabular}{|c|c|c|c|c|c|c|c|c|}
\hline \multirow[b]{3}{*}{ S.NO } & \multicolumn{4}{|c|}{ System precision } & \multicolumn{4}{|c|}{ Method precision } \\
\hline & \multicolumn{2}{|c|}{ Diacerein } & \multicolumn{2}{|c|}{ aceclofenac } & \multicolumn{2}{|c|}{ Diacerein } & \multicolumn{2}{|c|}{ aceclofenac } \\
\hline & PLS & PCR & PLS & PCR & PLS \% purity & PCR \% purity & PLS \% purity & PCR\% purity \\
\hline 1. & 3.00 & 3.00 & 6.01 & 6.01 & 100.12 & 100.12 & 100.43 & 100.43 \\
\hline 2. & 2.99 & 2.99 & 6.00 & 6.00 & 99.69 & 99.69 & 100.01 & 100.01 \\
\hline 3. & 3.00 & 3.00 & 6.01 & 6.01 & 100.76 & 100.76 & 101.08 & 101.08 \\
\hline 4. & 3.00 & 3.00 & 6.02 & 6.02 & 99.37 & 99.37 & 99.68 & 99.68 \\
\hline 5. & 3.00 & 3.00 & 6.01 & 6.01 & 99.39 & 99.39 & 99.70 & 99.70 \\
\hline 6. & 3.00 & 3.00 & 6.02 & 6.02 & 99.17 & 99.17 & 99.48 & 99.48 \\
\hline $\mathrm{AVG}$ & 3.00 & 3.00 & 6.03 & 6.03 & 99.75 & 99.75 & 100.06 & 100.06 \\
\hline S.D & 0.004 & 0.0043 & 0.02 & 0.02 & 0.5957 & 0.5957 & 0.597 & 0.597 \\
\hline$\%$ RSD & 0.146 & 0.1462 & 0.15 & 0.15 & 0.5972 & 0.5972 & 0.597 & 0.597 \\
\hline
\end{tabular}

Table 6: Recovery Studies

\begin{tabular}{|c|c|c|c|c|c|c|c|c|c|c|}
\hline \multirow{2}{*}{$\begin{array}{c}\text { \% of } \\
\text { Target }\end{array}$} & \multicolumn{5}{|c|}{ Diacerein } & \multicolumn{5}{|c|}{ Aceclofenac } \\
\hline & \multicolumn{3}{|c|}{ PLS } & \multicolumn{2}{|c|}{ PCR } & \multicolumn{3}{|c|}{ PLS } & \multicolumn{2}{|c|}{ PCR } \\
\hline \multirow{7}{*}{80} & $\begin{array}{c}\text { Added } \\
\text { mg }\end{array}$ & $\begin{array}{c}\text { Found } \\
\text { mg }\end{array}$ & $\begin{array}{c}\% \\
\text { Recovery } \\
\end{array}$ & $\begin{array}{c}\text { Found } \\
\text { mg }\end{array}$ & $\begin{array}{c}\% \\
\text { Recovery }\end{array}$ & $\begin{array}{c}\text { Added } \\
\text { mg }\end{array}$ & $\begin{array}{c}\text { Found } \\
\text { mg }\end{array}$ & $\begin{array}{c}\% \\
\text { Recovery } \\
\end{array}$ & $\begin{array}{c}\text { Found } \\
\text { mg }\end{array}$ & $\begin{array}{c}\% \\
\text { Recovery }\end{array}$ \\
\hline & 2.40 & 2.39 & 99.73 & 2.39 & 99.73 & 4.80 & 4.80 & 100.04 & 4.80 & 100.04 \\
\hline & 2.40 & 2.40 & 99.84 & 2.40 & 99.84 & 4.80 & 4.81 & 100.15 & 4.81 & 100.15 \\
\hline & 2.40 & 2.38 & 99.23 & 2.38 & 99.23 & 4.80 & 4.78 & 99.54 & 4.78 & 99.54 \\
\hline & \multirow{3}{*}{$\begin{array}{c}\text { Mean } \\
\text { SD } \\
\% \text { RSD }\end{array}$} & 2.39 & 99.60 & 2.39 & 99.60 & \multirow{3}{*}{$\begin{array}{c}\text { Mean } \\
\text { SD } \\
\% \text { RSD }\end{array}$} & 4.79 & 99.91 & 4.79 & 99.91 \\
\hline & & 0.01 & 0.33 & 0.01 & 0.33 & & 0.015 & 0.33 & 0.015 & 0.33 \\
\hline & & 0.33 & 0.33 & 0.33 & 0.33 & & 0.318 & 0.33 & 0.318 & 0.33 \\
\hline \multirow[t]{6}{*}{100} & 3.00 & 2.98 & 99.46 & 2.98 & 99.46 & 6.00 & 5.99 & 99.77 & 5.99 & 99.77 \\
\hline & 3.00 & 2.99 & 99.72 & 2.99 & 99.72 & 6.00 & 6.00 & 100.03 & 6.00 & 100.03 \\
\hline & 3.00 & 2.98 & 99.21 & 2.98 & 99.21 & 6.00 & 5.97 & 99.52 & 5.97 & 99.52 \\
\hline & \multirow{3}{*}{$\begin{array}{c}\text { Mean } \\
\text { SD } \\
\% \text { RSD }\end{array}$} & 2.98 & 99.46 & 2.98 & 99.46 & \multirow{3}{*}{$\begin{array}{c}\text { Mean } \\
\text { SD } \\
\% \text { RSD }\end{array}$} & 5.98 & 99.77 & 5.98 & 99.77 \\
\hline & & 0.01 & 0.25 & 0.01 & 0.25 & & 0.0152 & 0.26 & 0.015 & 0.26 \\
\hline & & 0.26 & 0.26 & 0.26 & 0.26 & & 0.255 & 0.26 & 0.255 & 0.26 \\
\hline \multirow[t]{6}{*}{120} & 3.60 & 3.60 & 100.00 & 3.60 & 100.00 & 7.20 & 7.22 & 100.32 & 7.22 & 100.32 \\
\hline & 3.60 & 3.59 & 99.68 & 3.59 & 99.68 & 7.20 & 7.20 & 99.99 & 7.20 & 99.99 \\
\hline & 3.60 & 3.58 & 99.51 & 3.58 & 99.51 & 7.20 & 7.19 & 99.82 & 7.19 & 99.82 \\
\hline & Mean & 3.59 & 99.73 & 3.59 & 99.73 & Mean & 7.20 & 100.04 & 7.20 & 100.04 \\
\hline & \multirow{2}{*}{$\begin{array}{c}\text { SD } \\
\% \text { RSD }\end{array}$} & 0.01 & 0.25 & 0.01 & 0.25 & \multirow{2}{*}{$\begin{array}{c}\text { SD } \\
\% \text { RSD }\end{array}$} & 0.015 & 0.25 & 0.015 & 0.25 \\
\hline & & 0.25 & 0.25 & 0.25 & 0.25 & & 0.212 & 0.25 & 0.212 & 0.25 \\
\hline
\end{tabular}

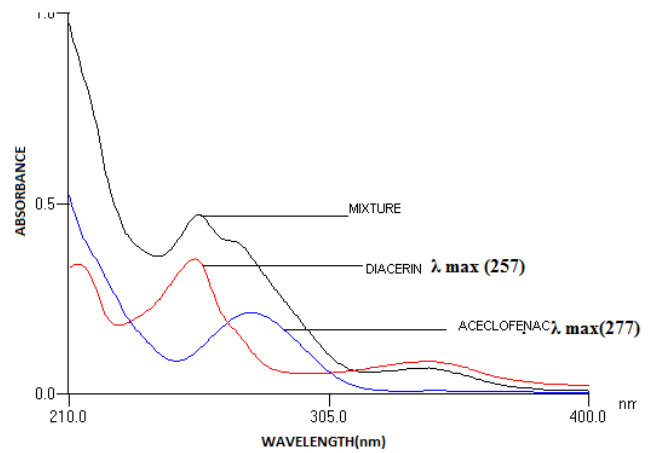

Figure 1 Overlaid UV Spectra of Diacerein, Aceclofenac and Mixture

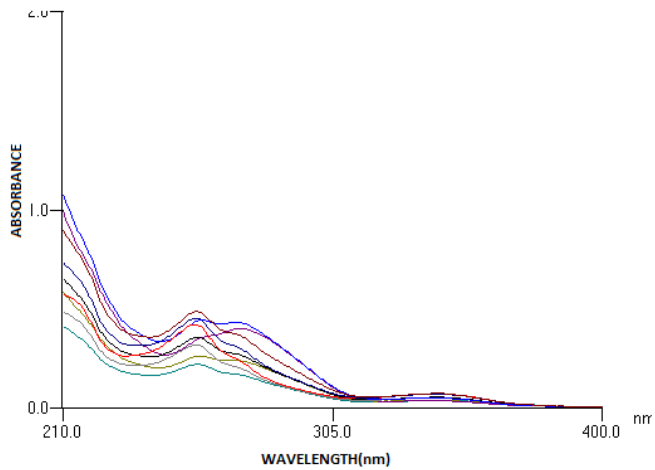

Figure 3 Prediction spectra of Diacerein and Aceclofenac

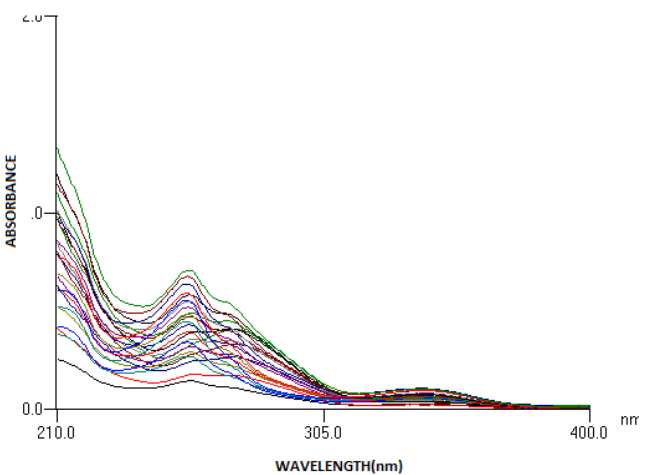

Figure 2 Calibration spectra of Diacerein and Aceclofenac

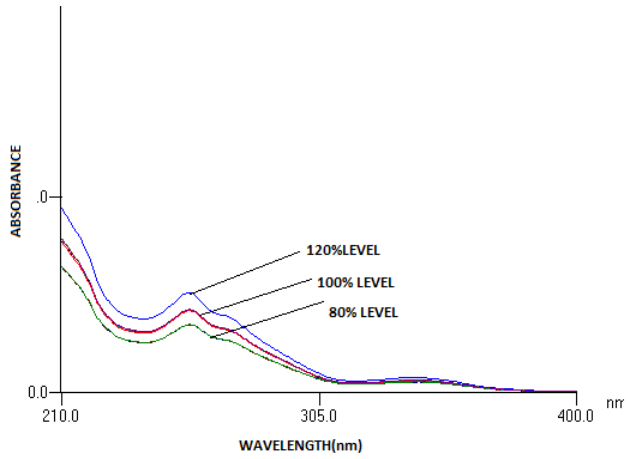

Figure 4 Recovery Spectra of Diacerein and Aceclofenac 
Experimental design of sample sets

Calibration and test sets for two component systems were designed according to factorial principle five-level factorial design was used to produce a calibration set (Training step) of 25 samples. Calibration spectra are shown in Figure 2. A three-level set was derived to produce a prediction set (Validation step) of nine samples. Prediction spectra are shown in Figure 3.The compositions of the used calibration and Validation sets are summarized in Tables 1 \& 2 respectively.

\section{Selection of optimum number of factors and the spectral region}

The most commonly employed validation criterion is to divide the dataset into two subsets, a calibration set and a validation set. The calibration model is calculated using the calibration set. Then, the root mean square errors of calibration and validation, RMSEC - root mean square error of calibration and RMSEP - root mean square error of prediction, are calculated using the calibration model under investigation to predict the samples in the calibration set and validation set, respectively. The results are presented in Table 3.

\section{Market Sample Analysis (Assay)}

The proposed PLS and PCR methods were applied to the simultaneous determination of DIA and ACE in commercial tablets. Determination of six replicates was made. Satisfactory results were obtained for each drug in good agreement with the label claims. The results are presented in Table 4.

\section{Precision}

The method was found to be precise with six sample preparations for the quantification of DIA and ACE. The precision and intermediate precision variations were calculated in terms of relative standard deviation and the results were found to be less than $2.0 \%$ and the results are presented in Table 5.

\section{Recovery Studies}

To check the validity of the proposed methods, recovery studies were carried out by addition of the standard to the pre-analysed formulation. (Standard addition technique) Recovery spectra are shown in Figure 4 and the results are presented in Table 6.

\section{CONCLUSION}

The most striking features of chemometric methods are its simplicity and rapidity without requiring time-consuming sample preparation. Chemometric calibration techniques in spectral analysis are widely used in quality control of drugs in mixtures and multi- component pharmaceutical formulations with overlapping spectra, as separation procedures in the drug determinations are not required. A comparative study of the use of PLS and PCR for the simultaneous spectrophotometric determination of diacerein and aceclofenac has been accomplished.

High percentage of recovery shows that the methods are free from interference of the excipients used in the commercial formulation. Results also showed that the developed methods can be applied to a routine analysis, quality control of mixtures and commercial preparations containing these drugs.

\section{ACKNOWLEDGEMENT}

The author thanks our management of C.L Baid Metha college of Pharmacy and Ideal Analytical Research Institution, Pondicherry for their Instrumental support of this investigation.

\section{REFERENCES}

1. Oneil MJ, Heckelman PE, Koch CB, In: The Merck Index, 14th ed., Whitehouse station, NJ,Merck and Co Inc., 2006. p. 503.

2. Toegel, S, Huang, W, Piana, C, Unger,M, Wirth M, Goldring MB, 2007.BMC Molecular Biology, p. 8, 13.

3. Indian Pharmacopoeia Vol II. Delhi: The Indian Pharmacopoeia commission; Published by the controller of Publication, 2007.p. 681.

4. Bhure M.V, Hemke A.T, K.R. Gupta. UV-Spectrophotometric Methods for Determination of Aceclofenac and Diacerein in Pharmaceutical Formulation.J. Pharm. Sci. \& Res. 2010;Vol.2 (7): 426-432.

5. Carolin Nimila I, Balan P, Yaswanth Kumar D, Rajasekar S. Simultaneous estimation of diacerein and aceclofenac in bulk and pharmaceutical dosage form by UV spectroscopy method. Int J PharmTech Res. 2010;2(4):2313-8.

6. Kesharwani Saurabh, Kohali Dharamveer. Development and validation of analytical methods for simultaneous estimation of diacerein and aceclofenac in bulk and tablets using UV-visible spectroscopy. Int J ChemTech Res. 2010;2(3):1816-22.

7. Mohammad Zameeruddin, Sayyed Nazim, Aejaz Ahmed, Shaikh Siraj. Simultaneous spectrophotometric determination of aceclofenac and diacerhein in tablet dosage form. Int J Chem Tech Res. 2011;3(2):791-4.

8. Ritu V. Kimbahune, Nikunjkumar Patel, Prachi V. Kabra, Bhavin Vaishnani, Vaibhav Deshmukhe, Narendra Sharath Chandra JN. Simultaneous spectrophotometric estimation of aceclofenac and diacerein in tablet dosage form. J Pharm Res. 2011;4(6):1757-9.

9. Sarika Narade, Snehal Patil, Sharda Surve, Dhanashri Shete, Yogesh pore. Simultaneous UV spectrophotometric method for the determination of diacerein and aceclofenac in tablets. J Pharm Sci Res. 2010;2(2):137-42.

10. Sohan S. Chitlange, Ganesh R. Pawbake, Amir I. Mulla, Sagar B. Wankhede. Simultaneous Spectrophotometric Estimation of Diacerein and Aceclofenac in tablet dosage form. Der Pharma Chemica, 2010; 2(1): 335-41.

11. Gandhi S.P,Dewani M.G, Borole T.C ,Damle M.C Development and validation of stability Indicating HPLC method for determination of Diacerein and aceclofenac as bulk drug and In tablet dosage form. Int J Res Pharm \& Chem.2011;1(4):799-806.

12. Jagadeeswaran M, Gopal N, Sivakumar T. Development and validation of a RP-HPLC method for simultaneous determination of diacerein and aceclofenac in tablet dosage form. Res J Pharm Biol Chem Sci. 2010;1(2):418-24.

13. Krishna R Gupta, Varun E. Samrit, Anuradha H Mahapatra, Sudhir G.Wadodkar. Stability indicating HPLC assay method for diacerein and aceclofenac in tablets.American Journal of PharmTech Research.2011;1(3):202-18.

14. Sekar V, Jayaseelan S, Udhaya Kumar E, Subash N, Prakash M, Perumal P. Development and validation of RP-HPLC method for the simultaneous estimation of diacerein and aceclofenac in dosage form. Int J ChemTech Res. 2010;2(1):168-71.

15. Siva kumar R, Srisutherson N, Sam Solomon WD, Kumar Nallasivan P, Venkatnarayanan R. Validated RP-HPLC method for the simultaneous estimation of aceclofenac and diacerein in bulk and formulation. Int J Pharm Tech Res. 2010;2(1):940-4.

16. Sharma MC, Sharma S. Application to dissolution studies and HPLC assay method for determination of diacerein and aceclofenac in tablet dosage form. Am-Euras J Sci Res. 2011;6(3):149-54.

17. Gandhi S.P, Dewani M.G, Borole T.C ,Damle M.C. Development and Validation of Stability Indicating HPTLC Method for Determination of Diacerein and Aceclofenac as Bulk Drug and in Tablet Dosage Form EJournal of Chemistry 2012;9(4):2023-28.

18. Santosh Bhalerao, Santosh Tambe, Vikas Pareek, Rupali Shinde, Lalit Kumar Gupta. A solid-liquid extraction and high performance thin layer chromatographic determination of diacerein and aceclofenac in pharmaceutical tablet dosage form. Asian J Pharma Clin Res. 2010;3(1):25-30.

19. Vigneau E, Devaux M.F, Qannari E.M, Robert P, 1997. Principal component regression, ridge regression and ridge principal component regression in spectroscopy calibration. J Chemom, 11, 239-49.

20. Brereton R, Chemometrics, Data Analysis for the Laboratory and Chemical Plant, Wiley, Chichester:2003.

\section{Cite this article as:}

Vijayageetha Ragupathy, Shantha Arcot. Simultaneous spectrophotometric determination of Diacerein and Aceclofenac in tablets by Chemometric methods. Int. Res. J. Pharm. 2013; 4(3):211-214 